\title{
Prudent and proactive board succession planning: A case study of selected companies in South Africa
}

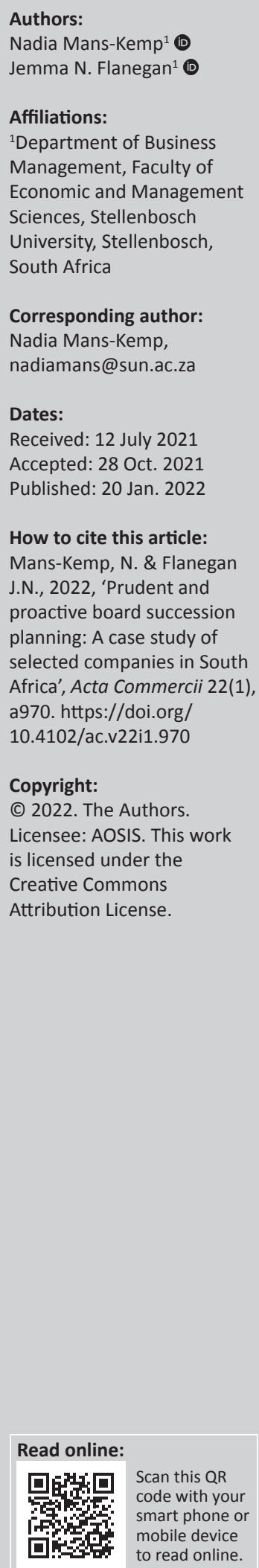

Orientation: The monitoring and advisory roles of directors are highlighted by escalating corporate uncertainty and diminishing confidence in leaders in the latest phase of the industrial revolution. Nomination committees should thus give due consideration to current and required human capital needs of boards when conducting succession planning, as their decisions have substantial implications for stakeholders.

Research purpose: To investigate board succession planning practices and policies at selected companies listed on the Johannesburg Stock Exchange.

Motivation for the study: There is an evident need for proactive succession planning that accounts for prudent board renewal and director development to ensure business continuity.

Research design, approach and method: Given the well-developed corporate governance framework in South Africa, the views of eight selected directors were gauged on succession planning by conducting semi-structured interviews. Thematic analysis was conducted to derive themes from the qualitative data.

Main findings: Nomination committees increasingly account for board composition concerns raised by prominent shareholders. The interviewees suggested that board succession planning is often not formalised. They mentioned that succession policies should be flexible to account for rapid change. Furthermore, the board development mechanisms applicable to executive and non-executive directors differ substantially. Proactive development of the talent pipeline is thus essential.

Practical/managerial implications: As heterogeneous boards offer several benefits to companies and their stakeholders, nomination committees should account for diversity considerations when conducting succession planning. Policies pertaining to tenure, diversity and independence should be formalised and annually evaluated and reported on.

Contribution/value-add: Several recommendations are offered to enhance board succession planning, based on the lived experiences of directors in an emerging market.

Keywords: succession planning; resource dependence theory; board diversity; independence; King IV; Industry 4.0.

\section{Introduction and rationale}

The fourth industrial revolution (Industry 4.0) brought about considerable changes to human capital that are required by companies to meet their evolving needs, thereby creating 'a perfect storm' for strategic workforce management (Whysall, Owtram \& Brittain 2019:118). Scholarly investigations of these types of company-environment interdependencies are typically derived from the resource dependence theory (Drees \& Heugens 2013). Companies accordingly depend on one another for the provision and sharing of essential resources to survive and prosper in their ever-changing environments (Hillman \& Dalziel 2003; Pfeffer \& Salancik 1978). Human resources play a key role in this regard (Hillman \& Dalziel 2003; Shaw, Park \& Kim 2013).

Researchers who investigated human capital as a competitive advantage largely focused on employees instead of corporate leaders (Khanna, Jones \& Boivie 2014). However, companies around the globe are increasingly challenged by the diminishing confidence of employees in the ability of their leaders to successfully navigate them during disruptive times (Odgers Berndtson 2020).

Scholars concur that the experiences and skills of board members can considerably impact their monitoring ability and the quality of advice that they offer (Johnson, Schnatterly \& Hill 2013; 
Khanna et al. 2014). Therefore, members of the Institute of Directors in South Africa (IoDSA) (Malan 2017) and the Australian Institute of Company Directors (2016) urged public companies to account for leadership refreshment to meet the challenges related to their constantly changing environments. Industry 4.0 brought about multiple challenges, inter alia related to interconnectivity and response time.

Similarly, practitioners and researchers encourage companies to formalise their succession planning procedures, especially for their top leaders (Schepker et al. 2018; Spencer Stuart 2018). Board succession planning should ensure that critical roles are properly fulfilled and that directors continuously sharpen their skills and knowledge (Wang, Jaw \& Tsai 2012).

Talent management is aptly described as a process that involves the identification, management and development of individuals to suit the current and future needs of companies (Cannon \& McGee 2011). It follows that talent managers including human resource departments and board nomination committees should consider the capabilities of individuals and the evolving requirements of their roles when (re)nominating them for leadership positions (Whysall et al. 2019).

As the external environment increasingly becomes 'chaotic', Lenkov (2020) advocated that talent management processes should be more structured and proactive. Effective succession planning can serve as a tool to improve the functioning of boards. Nomination committees should thus focus on sourcing, developing and retaining directors who can thrive despite growing corporate uncertainty and disruption (Odgers Berndtson 2020). According to Shaw et al. (2013), human capital is most valuable when employees are retained at companies where their skills, experience and knowledge have been honed.

Companies in South Africa grapple with complex issues such as how to address gender and race inequalities in the workforce and how to respond to skills gap (Seekings 2008). These aspects should be considered when conducting board succession planning, especially in the light of growing pressure on listed companies to diversify and continuously improve their leadership structures (Mans-Kemp et al. 2018; Mans-Kemp \& Viviers 2019).

This board succession study was conducted in South Africa as the country has a well-developed corporate governance framework (King IV). In addition, local shareholders are showing growing interest in board composition matters, specifically in the context of independence, gender and race diversity (Chartered Governance Institute of Southern Africa 2020). A hybrid corporate governance approach is prevalent in the country. This approach entails that companies that are listed on the Johannesburg Stock Exchange (JSE) should comply with relevant legislation and the JSE listings requirements. Furthermore, the 'apply and explain' approach proposed by King IV allows South African companies to reflect on how they can apply the guidelines in their unique contexts (IoDSA 2016:7).
The King IV Report specifically recommends that JSE-listed companies should set board race and gender diversity targets and annually report on their progress in this regard. Public companies are also expected to ensure that most of their board members are classified as independent non-executive directors (NEDs) (IoDSA 2016).

In contrast to executive directors, NEDs are not full-time employees of companies. The King IV Report prescribes that an NED who is classified as independent should not have an interest, position or association, which can unduly influence their decision-making. Furthermore, the competencies of directors should be continuously fostered to ensure that they remain effective leaders (IoDSA 2016). To this end, there is an evident need for proactive board succession planning that account for prudent board renewal and development to ensure business continuity in South Africa. Business continuity includes taking proactive steps to ensure that critical operations can proceed during a disruption (Wallace \& Webber 2017).

As business leaders are likely to experience increasing difficulties in managing rapidly changing stakeholder expectations in the future (Odgers Berndtson 2020), it is essential that talented leaders should be selected and continuously developed to ensure that they can effectively manage corporate threats and opportunities. Hence, the purpose of this study was to investigate board succession planning in South Africa. The objectives were threefold. Firstly, to explore prominent board succession strategies as described in the literature. Secondly, to conduct semi-structured interviews with selected directors serving on the boards of JSE-listed companies to reflect on board succession policies and practices. Thirdly, to offer suggestions on how board succession practices should evolve to enable directors and their companies to thrive despite the rapid changes and challenges associated with the latest phase of the industrial revolution.

In the remainder of the article, a theoretical overview will be provided to link the agency and resource dependence theories to board succession planning. The qualitative research methodology will then be explained. Thereafter, the findings will be linked to suggestions on how board succession planning can be enhanced in future.

\section{Literature discussion}

In this section, the agency and resource dependence theories will be covered, followed by an overview of succession planning approaches and selected board composition considerations.

\section{Agency and resource dependence perspectives}

In line with the agency and resource dependence theories, a board has several key responsibilities, including monitoring and advising management and ensuring optimal resource provision (Hillman \& Dalziel 2003; Nili 2020; Volonté \& Gantenbein 2016). Corporate leaders should thus be capable individuals who can effectively fulfil their divergent responsibilities. 
The separation of corporate ownership from control gave rise to the agency theory. The costly agency problem occurs when managers focus on self-interest instead of shareholders' best interests (Jensen \& Meckling 1976). Shareholders should, therefore, appoint directors who are independent of management so that these directors can monitor managerial and executive decision-making on the shareholders' behalf (Volonté \& Gantenbein 2016).

To enhance the overseeing role of a largely independent board, the leading positions of the chief executive officer (CEO) and board chairperson should ideally be separated. A lead independent director has a key monitoring role should the board chairperson also be the CEO. A lead independent director can then act as an intermediary between the board chair and other board members (IoDSA 2016).

Some authors have questioned the extent and effectiveness of managerial monitoring by independent directors. These authors' critique centres on the application of factual versus perceptual independence classification criteria (Khanna et al. 2014; Nili 2020). Factual independence refers to the number of years that an individual can serve in an independent capacity. A 9-year term limit is prescribed in King IV, where after the independence status of a director should be annually reviewed. Pertaining to perceptual independence, a nomination committee can be of the view that a specific board member can still exercise objective, unfettered judgement, despite exceeding this term limit (IoDSA 2016).

When assessing the independence of a director, Hom et al. (2021) suggested that the resource dependence theory should also be considered. This theory centres on the ability of directors to effectively respond to changes in their external environment and offer advice to management. Boards should ensure that their firms have access to the resources required to survive and prosper, including human resources (Pfeffer \& Salancik 1978; Volonté \& Gantenbein 2016).

Effective board succession planning is of particular importance for boards of directors given the influences of the latest stage of the industrial revolution on human capital development. From a resource dependence perspective, companies could use different internal and external succession planning methods to develop and retain board members, as will be explained next.

\section{Succession planning tactics and board composition considerations}

Board succession planning ensures the systematic replacement of executive, non-executive and independent board members. The nomination committee is primarily responsible for this key human resource management task (Deloitte 2017a). Professional search firms could assist them to source candidates with specific characteristics (Zhang \& Rajagopalan 2010).

The ability of a board to perform advisory and monitoring roles is influenced by the heterogeneity of its members, as explained by the agency and resource dependence theories (Harjoto, Laksmana \& Yang 2018; Ntim 2015). Boards that are diverse regarding their directors' experience and functional expertise tend to exhibit better corporate oversight than homogeneous directorates. For this reason, institutional investors and regulators globally are encouraging companies and particularly nomination committees, to diversify their boards (Harjoto et al. 2018).

Nomination committees should, therefore, account for independence, tenure and diversity considerations when they nominate or renominate directors or source board candidates. This committee should also identify skills gap and training needs (Deloitte 2017a). Strategic resource management initiatives should thus focus on developing and sustaining a strong talent pipeline (Kim et al. 2014).

Furthermore, nomination committees should ensure that their companies' human capital is optimally leveraged not only to enhance productivity but also to ensure that the companies' leaders can effectively respond to changes and challenges in the dynamic corporate environment (Wang et al. 2012). The proposed board succession policy and related development initiatives should be thoroughly discussed with board members before being implemented (Spencer Stuart 2018).

The unique context of a company should be considered when reflecting on the most suitable board succession approach (Minichilli et al. 2014). Although succession planning can be structured in line with planned retirements, nomination committees should also do emergency planning when unforeseen events occur, for example, if a board member passes away. From an agency theory perspective, the influence of the CEO on director selection processes should be limited (Eminet \& Guedri 2010).

\section{Overview of commonly used board succession approaches}

Nomination committees can use internal methods to fill board positions or they can source candidates externally (Tao \& Zhao 2019). Relay succession, horse-race succession and the compilation of a skills matrix are prominent internal succession planning methods (Minichilli et al. 2014; Spencer Stuart 2018; Tao \& Zhao 2019).

Relay succession entails the timeous identification of a so-called 'heir' apparent for a leading position, such as the CEO. The identified successor is then 'groomed' for the foreseen future leadership position (Tao \& Zhao 2019:61). A considerable advantage of using this method to timeously plan for successions is the ease of shifting power, which counteracts corporate disruption (Zhang \& Rajagopalan 2006). However, if nomination committees do not sensitively deal with this matter, they might alienate some directors and lose valuable human capital (Australian Institute of Company Directors 2016). 
In the case of horse-race succession planning, several corporate insiders compete for a specific board position. This method can be applied when there is a large internal talent pool. Several candidates can then be coached by directors. The candidates' progress can be closely observed by the nomination committee and their predecessor who is nearing retirement (Minichilli et al. 2014). As this method results in corporate 'winners and losers', invaluable human capital can be lost if key individuals leave the company in response to the outcome of the 'corporate race' (Mulcahy 2010).

Furthermore, several authors and practitioners suggest that nomination committees should compile a skills matrix to visualise the extent of their future human capital needs at board level (Australian Institute of Company Directors 2016; Dalton \& Dalton 2005; International Corporate Governance Network [ICGN] 2018; Schepker et al. 2018). Based on this assessment, directors could receive training to enhance their ability to fulfil their current roles. Development opportunities could also enhance the chances of board members to be considered for leading roles in the future, such as the board chair or lead independent director (Zhang \& Rajagopalan 2010).

Talent practitioners anticipate a greater reliance on internal sourcing methods in the future (Chartered Institute of Personnel and Development 2017). Schepker et al. (2018) explained that the likelihood of disruption during executive leadership transitions will decrease if internal succession endeavours are formalised. If the selected internal successor has a thorough understanding of the operational aspects, uncertainty and disruption will be limited when the leadership transition occurs.

Deliberations on the void between the skills of directors and those required by companies will have an impact on whether candidates are internally sourced and developed or externally recruited (Makarius \& Srinivasan 2017; Tao \& Zhao 2019). Internal development initiatives are typically aimed at meeting predictable succession needs, for example, in the case of retirements. External recruiting consultants could assist nomination committees to fill unpredicted vacancies (Cappelli 2008). Nomination committees should consider that although outside executive candidates can offer fresh perspectives on operational and board matters (Bailey \& Helfat 2003), they often lack the firm-specific knowledge of insiders (Zhang \& Rajagopalan 2010). Corporate outsiders might therefore require substantial training following their appointments.

The ability of executives and top managers to retain their positions largely depends on how effectively they deal with environmental contingencies (Pfeffer \& Salancik 1978). Although some leading companies have sophisticated board succession policies, a considerable number of firms still globally follow 'haphazard' director succession approaches (ICGN 2018).
Nomination committees should thus ensure that their companies' top leadership structures are constantly (re) aligned to address the challenges and explore the opportunities related to the ever-changing corporate environment (Shen \& Cho 2005). They should also account for independence and diversity when reflecting on board succession (IoDSA 2016).

\section{Director independence, tenure and diversity}

Local nomination committees should give due consideration to director independence, the number of years that each director serves in a specific position (tenure) and diversity when contemplating board appointments, as these are prominent aspects mentioned in the King III and IV Reports (IoDSA 2009, 2016). The King IV prescribes that most NEDs should be classified as independent (IoDSA 2016). The NEDs and independent directors are not responsible for the companies' daily operations but should advise and monitor management (Nili 2020). The King IV Report urges all board members, irrespective of their independence status, to act with an independent mind and in their companies' best interests (IoDSA 2016).

If concerns arise amongst shareholders that long-tenured independent NEDs have become entrenched, thereby losing their monitoring ability, corporate owners are likely to call for board refreshment (Livnat et al. 2019). When appointing new board members, board refreshment entails that nomination committees should account for independence, tenure and diversity. A balanced view should be adopted when nomination committees contemplate board refreshment and director term limits. They should account for the performance of long-tenured, experienced directors and the potential new perspectives that diverse candidates can offer (Livnat et al. 2019; Spencer Stuart 2018).

The King IV Report advises that JSE-listed companies should set board race and gender targets and annually report on their progress in this regard (IoDSA 2016). Despite the voluntary compliance approach of King IV, several of its recommendations, including director independence and reporting on board race and gender targets, have been incorporated in the JSE listings requirements. Nomination committees should therefore thoroughly check the backgrounds, qualifications and independence classification of board candidates before shareholders can (re)appoint directors by casting their votes at annual general meetings (Deloitte 2017a).

The results of the 2020 leadership confidence survey conducted by Odgers Berndtson (2020) showed that companies should 'reinvent leadership for the modern world' (Scrope, Braithwaite \& Potter 2020). The preceding literature discussion confirms that nomination committees should ensure that their boards comprise eligible individuals who can effectively guide their companies during uncertain times. Board succession planning and the outcomes therefore warrant further investigation, especially in South Africa given the well-developed corporate governance framework and 
growing investor scrutiny of board composition matters. The first research objective was addressed by providing an overview of board succession strategies in the literature review section. To address the second objective, semi-structured interviews were conducted, as explained next.

\section{Qualitative research methodology}

Drawing on an interpretivist perspective, semi-structured interviews were conducted with selected executive and non-executive board members of eight locally listed companies. A combined descriptive-exploratory approach was adopted to reflect on board succession policies and practices in South Africa.

\section{Development of the interview guide}

The semi-structured interview guide was compiled from relevant literature and the King IV Report on corporate governance (IoDSA 2016). Biographic details of the participants were requested in the first section of the guide, including their tenure and area(s) of expertise. The second section of the interview guide covered various main and additional questions. Examples of these questions (the additional questions indicated in brackets) are as follows:

- Do you source board candidates internally or externally? (Do you use consultants? If consultants are used, do they play a leading role in the process?)

- How does your company contribute to developing the local talent pool? (Do you make use of bursaries, internships or other programmes to support potential board candidates?)

- Have you noticed enhanced shareholder activism on director independence and tenure? (Is your succession planning policy disclosed to shareholders?)

- What are the main benefits that you associate with board succession planning? (Do you have any other suggestions to enhance board succession planning in future?)

\section{Sample description}

As board succession planning applies to all listed companies and the King IV guidelines do not differentiate between industries (IoDSA 2016), the sample was not limited to board members serving companies operating in a specific industry in South Africa. Furthermore, given their divergent managerial, monitoring and advisory roles (Nili 2020), both executive and non-executive board members were approached to participate in this study.

Snowball sampling was used to identify board members of JSE-listed companies who were willing to be interviewed on board succession planning matters. Initial contact was made via the researchers' networks. Thereafter, some interviewees made referrals to other potential participants. Interviews were conducted with eight directors, three of whom were classified as executive. The other five participants were independent NEDs of whom one acted as a board chair. The interviewees had served on multiple boards of JSE-listed companies. Their average tenure was four years, and their focus areas included asset management, accounting and human resources.

Given the outbreak of the coronavirus disease 2019 (COVID-19), all interviews were conducted virtually via Microsoft (MS) Teams and Zoom. When conducting qualitative research, Vasileiou et al. (2018:2) confirmed that interview samples tend to be small and purposefully selected to provide 'richly textured information'. Although the sample size of this study was relatively small, the interviewees were experienced board members who offered informed views on board succession planning. They provided valuable suggestions to enhance succession planning policies and practices.

\section{Trustworthiness of the thematic analysis}

The six-step thematic analysis approach outlined by Braun and Clarke (2006) was used to analyse the collected interview data. The first step entailed that the researchers become familiarised with the collected qualitative data, by reading the transcriptions and notes made during the interviews. Preliminary inductive codes were then assigned to describe the content of the data (step two). The third step entailed searching for themes. Colour coding and tables were used to identify preliminary themes. During step four, the themes were reviewed, and four themes were finalised during the fifth step. The last step entailed reporting the findings.

Pertaining to transferability, the interviewees had considerable governance experience and could therefore offer informed opinions on the topic. Although the findings are not generalisable to all JSE-listed companies, the recommendations might be of value to directors working in various industries. To enhance confirmability, the recorded interviews were systematically transcribed and checked to ensure that the reported results are consistent with the recordings. The researchers attempted to objectively report the participants' views. Selected responses were clarified with the interviewees. Direct quotes were inserted to contextualise the findings.

\section{Ethical considerations}

Ethical clearance to conduct this study was obtained from the Research Ethics Committee: Social, Behavioural and Education Research (SBER) of the Stellenbosch University (reference number: 15088) before the interviews were conducted. In line with the informed consent form, participants had the opportunity to withdraw from the study during any stage, in which case the recorded interview would have been discarded in their presence. No participant withdrew from the study. To ensure their anonymity, none of the participants have been identified in the findings section.

\section{Findings and discussion}

The second research objective is addressed by reporting on four main themes, namely (1) the nature of board succession planning, (2) director development initiatives, (3) enhancing 
board diversity and independence through succession planning and (4) suggestions to improve future board succession planning endeavours.

\section{Nature of board succession planning}

Participants explained that the selected board succession planning approach at their companies is linked to the reason(s) for searching for a potential successor. Reference was made to long-term retirement planning and emergency planning to replace a deceased director. The leadership consultant company Spencer Stuart (2018) likewise recommended that nomination committees should adopt a multi-year view that allows flexibility for emergency sourcing. All interviewees mentioned that their board succession policies were reviewed at least once a year. Most of them indicated that succession planning was prioritised during their board meetings, in line with a best practice guideline suggested by Spencer Stuart (2018).

Interviewees indicated that board members generally gave a sufficient period of notice before retiring. However, emergency succession planning applied when sudden retirement occurred or when directors in key positions were 'poached' by competitors. Amankwah-Amoah (2018:735) confirmed the tendency of companies to respond to rapidly changing human resource needs by 'poaching' talented individuals. The aim of such lateral recruitment is typically to hire a perceived expert (Whysall et al. 2019). This term refers to retaining talent in a company by moving an individual between departments or positions.

Participants explained that some individuals could shift positions to fulfil key roles on short notice in a case of emergency. The following example was provided by an interviewee in line with a King IV recommendation: When the role of the board chair, a key leadership position, unexpectedly became vacant, the lead independent director was likely to take up that role, either in a permanent or a temporary capacity. Krause, Withers and Semadeni (2017) concurred that the lead independent position became institutionalised to enhance independent monitoring, especially if the CEO also held the board chair position. None of the considered boards had such role duality.

Although all participants had some form of a succession plan in place at their boards, the formality of the succession plan differed. Six interviewees mentioned that their boards had a formal policy. A counterpart described their board succession as an 'informal yet informed process'. The literature suggests that board succession processes should preferably be formalised (Concannon \& Nordberg 2018).

The interviewees highlighted considerable differences between the succession plans for executive directors and those for NEDs owing to their divergent roles. They described the retirement of NEDs as 'easy to plan for' and 'smoothly managed'. In addition, they indicated that succession planning was typically better documented for executives than for NEDs. One participant remarked that
TABLE 1: Internal succession planning strategies of the considered boards.

\begin{tabular}{lccc}
\hline Interviewee & Relay & Horse-race & Skills matrix \\
\hline 1 & $\mathrm{x}$ & - & - \\
2 & - & $\mathrm{x}$ & - \\
3 & $\mathrm{x}$ & - & $\mathrm{x}$ \\
4 & - & - & $\mathrm{x}$ \\
5 & - & - & $\mathrm{x}$ \\
6 & $\mathrm{x}$ & $\mathrm{x}$ & $\mathrm{x}$ \\
7 & - & - & $\mathrm{x}$ \\
8 & - & - & $\mathrm{x}$ \\
\hline
\end{tabular}

the 'replacing of non-executives is a much slower process than if you are looking to fill an executive position'. This tendency relates to the urgency of replacing an executive who fulfils a crucial operational role. Schepker et al. (2018) highlighted a research gap to investigate the nature and outcomes of directorate succession planning procedures. The strategies reported in this article relate to internal succession planning and sourcing of board candidates.

\section{Internal succession planning strategies}

Table 1 provides an overview of the internal succession planning approaches of the considered boards.

Table 1 shows that the considered directors' nomination committees preferred to compile a skills matrix to assess their current and future human capital requirements at the stage when the respective interviews were conducted. Dalton and Dalton (2005) confirmed that nomination committees commonly use this approach to enhance their boards' composition and abilities.

When conducting a skills assessment, one of the interviewees explained that individuals can nominate themselves for specific board and committee roles should they feel equipped to do so. This participant explained that there are lots of really cognisant people who just quietly go along'. By allowing self-nomination, the nomination committee can become aware of their ambitions to fill specific positions. Pertaining to relay succession, some interviewees explained that individuals were appointed to specialised board committees to gain experience to be considered for more senior roles in the future.

In line with Makarius and Srinivasan (2017), several participants emphasised the importance of timeously identifying skills gap. Most of the interviewees referred to the usage of a skills matrix, as shown in Table 1. The interviewees made specific reference to the relevance of information technology (IT) skills to respond to the challenges and opportunities related to Industry 4.0. Valentine and Stewart (2013) reiterated the importance of having technology-savvy leaders. Stephan, Kamen and Bannister (2017:83) likewise referred to a preference for appointing 'tech fluent' leaders. Such individuals will exhibit proficiency in terms of their understanding of technology principles and systems.

The interview guide did not specifically focus on CEO succession. Yet several of the interviewees explicitly 
mentioned CEO succession planning, given the key roles that such leaders play in companies. As indicated in Table 1, two participants referred to the horse-race succession method. They explained that this method is generally applied informally to fill the CEO position. One of them remarked that an informal race was 'not quite as ego-hurting' and cautioned that a formalised approach might result in the departure of valuable employees. Mulcahy (2010) echoed this concern. In contrast, Leblanc (2020) proposed that the horse-race method should be formalised. Each candidate should accordingly receive a formal development plan and their progress should be monitored by the nomination committee and the individual who currently fulfils the leadership role.

\section{Internal and external sourcing of board candidates}

In line with a King IV recommendation (IoDSA 2016), all interviewees indicated that the sourcing of board candidates was the primary responsibility of the nomination committee. They mentioned that their nomination committees mainly comprised senior NEDs who typically sourced board candidates through their existing networks. An interviewee indicated that internal sourcing was preferred to fill executive positions. This view could be partly explained by the observation of Zhang and Rajagopalan (2010) that external executive candidates typically lack firm-specific operational knowledge.

Scholars caution against excessive reliance on nomination committees' existing networks to source board candidates. Fracassi and Tate (2012) made specific reference to the potential negative impact on corporate governance compliance should board candidates have network ties with powerful corporate leaders such as the CEO. Two participants in this study expressed similar concerns and cautioned against possible conflicts of interest.

A counterpart mentioned that networking could be 'very useful to identify diverse board candidates'. Likewise, Dennissen, Benschop and Van den Brink (2019) indicated that companies should reflect on the barriers to inclusion of diverse individuals in corporate ranks. Nomination committees should also consider the compilation of their existing networks from where they source board candidates and the potential impact thereof on board diversity.

All interviewees mentioned instances where their nomination committees used consultants to assist with board succession matters. Four participants specified that consultants were used when appointing executives and recruiting individuals with a very specific skills set. However, two of the participants observed that they did not have notably successful outcomes in this regard.

The participants explained that consultants were briefed on specific requirements of external board candidates. The consultants should then conduct background checks and provide a shortlist to the nomination committee. All the interviewees stated that if consultants were used, the final decision to nominate specific candidates should be left to the board, assisted by the nomination committee. Whysall et al. (2019), Amankwah-Amoah (2018) and Zhang and Rajagopolan (2010) likewise cautioned against over-reliance on search firms and lateral hiring.

After shareholders are briefed on board candidates' profiles, they cast their votes. Shareholders then make the ultimate decision to appoint directors (IoDSA 2016). An interviewee indicated that shareholders' involvement in board succession planning could be enhanced by casting a 'mindful vote' at the annual general meeting. A counterpart observed that although shareholders are not directly involved in formulating board succession policies, their views (and by implication their votes) can substantially affect the implementation of these policies. The Chartered Governance Institute of Southern Africa (2020) reaffirmed that local shareholders are showing growing interest in board composition.

\section{Director development initiatives to meet existing needs and to grow the talent pool}

Two integral considerations of board succession planning are the development of directors and initiatives to enlarge the talent pool from which board candidates can be selected (Spencer Stuart 2018). In this respect, all the interviewees emphasised the importance of developing the talent pipeline to ensure business continuity.

Furthermore, the participants explained that their board development programmes were generally linked to operational considerations that were particularly relevant to executive positions. As a result, all interviewees deemed executive training imperative to succession planning. In line with the findings of Mans-Kemp et al. (2018) and D'Abate, Eddy and Tannenbaum (2003), six participants mentioned that informal mentorship is often provided to executive candidates.

Participants stated that NEDs are typically experienced individuals who possess the required skills to fulfil their roles. The implication is that individuals are appointed as NEDs on account of their skills. The participants explained that development initiatives offered to NEDs are generally aimed at keeping them up to date with legislation and developments linked to their professions. A participant commented that 'you should want to develop your skills and stay on top of your game'. In line with MansKemp et al. (2018), some counterparts agreed that director development is dependent on the proactivity of individuals.

All participants deemed orientation essential for all newly appointed board members, irrespective of their prior experiences. They indicated that orientation typically offers an overview of company-specific knowledge. The King 
IV Report reiterates the importance of offering an in-depth introduction programme to board appointees (IoDSA 2016). Some interviewees mentioned that companies could also consider offering mentorships for NEDs and more in-depth orientation programmes.

The interviewees made several suggestions to grow the local talent pool from which board candidates can be sourced. They suggested offering bursaries, internships and graduate programmes to promising, diverse individuals. The interviewees mentioned that their companies annually reported on these talent development initiatives. PricewaterhouseCoopers (PwC 2019) also indicated that similar initiatives complement the succession plans of various locally listed companies.

\section{Enhancing board composition through succession planning}

Several participants indicated that diversity, director independence and tenure should be considered when deliberating board refreshment.

\section{Views on board gender and race diversity}

A participant remarked that 'you need diversity to be able to efficiently operate in a diverse environment'. Counterparts also agreed that their nomination committees accounted for diversity considerations, specifically race and gender when formulating their board succession policies. Although one interviewee confirmed that 'formal targets are set and signed off' at their company, all interviewees' boards have not yet formalised board gender and race diversity targets.

To make shareholders more aware of their initiatives to enhance board diversity, the companies on whose boards the participants served annually reported on how they attempted to diversify their boards. In line with Viviers, Mans-Kemp and Fawcett (2017), several participants mentioned that local shareholders focus on female board representation. Deloitte (2017a) pointed out that board gender diversity is one of the most emphasised board composition considerations globally. Female board representation is gradually increasing in South Africa (Deloitte 2017a). Interviewees indicated that board diversity could be further enhanced by formalising gender and race targets at all JSE-listed companies.

\section{Accounting for director independence and tenure}

The interviewees confirmed that independence, tenure and board refreshment considerations formed part of their directorate evaluations and board succession deliberations. All of them indicated that formal board evaluations occurred either once a year or every second year as proposed by King IV (IoDSA 2016).

The largely subjective nature of independence assessments was highlighted by several participants. In line with Van den Berghre and Baelden (2005) and the King IV Report (IoDSA 2016), reference was made to 'independence of thought'. This concept relates to being more reliant on the character of individuals and their ability to make independent decisions, rather than focusing on a strict structural definition of director independence. Van den Berghe and Baelden (2005) confirmed that those directors who are formally defined as independent might not necessarily be independent of mind. All interviewees emphasised the importance of having a balance of independent NEDs and executive members on a board.

All participants deemed the King IV (IoDSA 2016) prescribed tenure period of nine years for independent directors a mere guideline. One of them stated that there is 'no hard and fast rule' pertaining to independent director tenure. Should the independence status of a director be at stake because of a tenure period longer than nine years, an interviewee suggested that an additional independent NED or lead independent NED should be appointed 'to create balance again'. That being the case, directors are urged to account for the potential detrimental effects should they have undisclosed conflicts of interest.

A counterpart mentioned that such a balance could affect 'your scoring in terms of King IV'. Clements et al. (2018) found a significant positive relationship between tenure and the quality of the services provided by directors at low and intermediate tenure levels. However, they noticed a significant negative link when tenure became very lengthy. Although these authors suggested that companies should deliberate term limits on a case-by-case basis, they cautioned against prescribing a fixed limit. Sun and Bhuiyan (2020) also supported flexibility in this regard.

Most interviewees remarked that longer-tenured board members tend to add substantial value to their boards. They explained that a longer tenure typically implies that a director has accumulated considerable experience and companyspecific knowledge. Despite the substantial benefits of having board members who are very familiar with their companies, Daily, Dalton and Cannella (2003) asserted that substantial agency costs can be incurred should conflicts of interest arise.

In view of the concern that a longer tenure might affect the independence status of a director, the interviewees suggested that tenure and independence should be reviewed in combination. Participants explained that such evaluations could typically take the form of personal assessments or questionnaires evaluated by an impartial third party. Deloitte (2017b) confirmed that such evaluations can be very useful to identify weaknesses and to showcase strengths of a board.

Half of the interviewees observed that shareholders increasingly showed interest in tenure and director independence. They thus proposed that companies should demonstrate to shareholders that these concerns would be considered when conducting succession planning. Although succession policies are typically not disclosed to shareholders in detail, participants stated that shareholders should have 
the right to ask questions about such plans, for example, at shareholder meetings.

\section{Suggestions to improve future board succession planning endeavours}

Although most interviewees regarded their board succession planning policies as sufficient, scope for improvement was mentioned. A participant remarked that 'a lot of companies will have succession plans; it is a question of how realistic they are'. Most interviewees observed the ever-changing nature of board succession planning. One of them emphasised that a 'one size fits all' succession approach should be avoided. Given the advent of Industry 4.0, Whysall et al. (2019) likewise highlighted the dynamic nature of succession planning and strategic human resource management.

A participant stressed that succession planning should not merely be a 'paper exercise'. This participant explained that although there was a set policy on paper 'it is quite difficult in reality [to comply with the policy]' and, in some cases, the policy would thus not match actual implementation. As local shareholders are progressively expressing interest in board composition matters (Chartered Governance Institute of Southern Africa 2020), it is likely that nomination committees will be increasingly held responsible for their board development programmes and empowerment initiatives.

The interviewees argued that the maintenance of institutional knowledge would become more challenging if several directors retired at the same time. Accordingly, all participants mentioned the use of a staggered approach to director retirement (also referred to as a 'rolling succession'), as proposed by King IV (IoDSA 2016). This approach implies that directors could retire after their prescribed term or stand for re-election (IoDSA 2016).

Another participant emphasised the importance of continuous board succession planning, adding that a strategic approach is needed by 'looking 5 or 10 years ahead'. Practitioners agree that board succession policies should be continuously assessed to respond to unexpected situations (Spencer Stuart 2018). Given the growing uncertainty, especially in light of the COVID-19 pandemic, companies and their nomination committees are likely to increasingly reflect on how they can enhance and better utilise their human resources.

\section{Conclusion, recommendations and limitations}

Listed companies in South Africa have a well-developed corporate governance framework (King IV) at their disposal to guide them in developing and implementing board succession policies. In addition to offering guidance on a balanced board structure comprising independent directors, NEDs and executives, the King IV Report recommends that board gender and race diversity targets should be set and disclosed to shareholders. These targets are often linked to director development initiatives. The nomination committee is a key role player in the board succession process.

The researchers reflected on various board succession planning strategies that nomination committees can use to enhance their leadership structures to address the first objective. Semi-structured interviews were then conducted with selected directors serving on the boards of JSE-listed companies to gauge their views on board succession endeavours to meet the second research objective. The third research objective is addressed by offering recommendations to nomination committees, board members and shareholders, based on the thematic findings, to improve board succession policies and practices in future.

The interviewees indicated that their boards regarded succession planning as essential to ensure business continuity. Their nomination committees commonly used a skills matrix to account for current and future human capital requirements of their directorates and board committees. Marked differences were observed in the succession planning approaches adopted for executives and NEDs. Nomination committees are advised to ensure that they retain their leading role in the director nomination process should they use consultants.

Participants largely ascribed the observed lack of strictly enforced rules for director independence and tenure to the subjective and intertwined nature of these board succession matters. Most interviewees valued the experience of longertenured directors. They also observed growing shareholder interest in board succession planning, specifically regarding gender diversity, director independence and tenure.

Nomination committees are accordingly advised to formalise policies on board tenure, diversity and independence. They are furthermore encouraged to engage more regularly with key shareholders to discuss board composition concerns. In turn, companies should ensure transparent reporting on board succession considerations, including independence classifications and diversity policies. Deviations from the King IV nine-year term limit should be explained. Potential and actual shareholders will then be able to make more informed decisions. In turn, shareholders are urged to give due consideration to the profiles of board candidates before casting their votes.

The participants suggested that board development initiatives should be linked to board succession planning. Although they mentioned that these initiatives were largely aimed at executives, nomination committees are advised to offer continuous development opportunities to all directors. Directors are also encouraged to enhance their skills proactively and continuously to properly fulfil their divergent and evolving roles, as described by the agency and resource dependence theories. 
In this study, the usage of snowball sampling largely resulted in referrals to peers in the same industry. Future scholars could conduct a quantitative study by developing and distributing a survey to directors serving in all JES-industries. Future authors could also conduct interviews with directors serving on the boards of listed companies not only in South Africa but also in other emerging countries such as Brazil, Russia, India and China. They could then compare these directors' views on board succession planning policies, practices and development initiatives, whilst accounting for country-specific challenges and opportunities.

As companies are likely to experience escalating uncertainty in future, it is essential that nomination committees should timeously identify and develop talented leaders. The recommendations offered for proactive succession planning and prudent board renewal could enhance directors' abilities to meet challenges and utilise opportunities related to Industry 4.0.

\section{Acknowledgements Competing interests}

The authors declare that they have no financial or personal relationships that may have inappropriately influenced them in writing this article.

\section{Authors' contributions}

N.M.-K. conceptualised and wrote the article. J.N.F. collected and analysed the data and contributed to the literature review.

\section{Funding information}

This work is based on the research supported in part by the National Research Foundation of South Africa (Grant number: 121880).

\section{Data availability}

The data cannot be made available to protect the anonymity of the participants.

\section{Disclaimer}

The views and opinions expressed in this article are those of the authors and do not necessarily reflect the official policy or position of any affiliated agency of the authors, and the publisher.

\section{References}

Amankwah-Amoah, J., 2018, 'Human capital flows in failing organizations: An integrated conceptual framework', Journal of Intellectual Capital 19(4), 732-746. https://doi.org/10.1108/JIC-05-2017-0065

Australian Institute of Company Directors, 2016, Succession planning: Board composition, viewed 08 June 2021, from https://aicd.companydirectors.com. $\mathrm{au} / \sim /$ media/cd2/resources/director-resources/director-tools/pdf/05446-5-memdirector-tools-bc-succession-planning_a4_web.ashx.

Bailey, E.E. \& Helfat, C.E., 2003, 'External management succession, human capital, and firm performance: An integrative analysis', Managerial and Decision Economics 24(4), 347-369. https://doi.org/10.1002/mde.1119
Braun, V. \& Clarke, V., 2006, 'Using thematic analysis in psychology', Qualitative ResearchinPsychology3(2),77-101.https://doi.org/10.1191/1478088706qp063oa

Cannon, J.A. \& McGee, R., 2011, Talent management and succession planning, 2nd edn., Chartered Institute of Personnel Development, London.

Cappelli, P., 2008, 'Talent management for the twenty-first century', Harvard Business Review 86(3), 74-81.

Chartered Governance Institute of Southern Africa, 2020, Shareholder activism and the role of the company secretary, viewed 09 June 2021, from https://chartsec. co.za/documents/members/CGISA $\% 20$ Best $\% 20$ Practice $\% 20$ Guide $\% 20$ Shareholder\%20Activism.pdf.

Chartered Institute of Personnel and Development, 2017, Resourcing and talent planning: Survey report, viewed 08 June 2021, from https://www.cipd.ae/Images/ resourcing-talent-planning_2017_tcm22-23747.pdf.

Clements, C.E., Jessup, R.K., Neill, J.D. \& Wertheim, P., 2018, 'The relationship between director tenure and director quality', International Journal of Disclosure and Governance 15(3), 142-161. https://doi.org/10.1057/s41310-018-0042-2

Concannon, M. \& Nordberg, D., 2018, 'Boards strategizing in liminal spaces: Process and practice, formal and informal', European Management Journal 36(1), 71-82. https://doi.org/10.1016/j.emj.2017.03.008

D'Abate, C.P., Eddy, E.R. \& Tannenbaum, S.I., 2003, 'What's in a name? A literaturebased approach to understanding mentoring, coaching, and other constructs that describe developmental interaction', Human Resource Development Review 2(4) 360-384. https://doi.org/10.1177/1534484303255033

Daily, C.M., Dalton, D.R. \& Cannella, A.A., 2003, 'Corporate governance: Decades of dialogue and data', Academy of Management Review 28(3), 371-382. https://doi. org/10.5465/amr.2003.10196703

Dalton, C.M. \& Dalton, D.R., 2005, 'Boards of directors: Utilizing empirical evidence in developing practical prescriptions', British Journal of Management 16(1), 91-97. https://doi.org/10.1111/j.1467-8551.2005.00450.x

Deloitte, 2017a, King IV: Diversity in the boardroom, viewed 15 September 2020, from https://www2.deloitte.com/content/dam/Deloitte/za/Documents/governancerisk-compliance/za_Deloitte_KingIV_Board_Diversity_01032017.pdf.

Deloitte, 2017b, Duties of directors, viewed 14 September 2020, from https://www2. deloitte.com/content/dam/Deloitte/za/Documents/governance-riskcompliance/ZA_Duties-Of-Directors_101017.pdf.

Dennissen, M., Benschop, Y. \& Van den Brink, M., 2019, 'Diversity networks: Networking for equality', British Journal of Management 30(4), 966-980. https:// doi.org/10.1111/1467-8551.12321

Drees, J.M. \& Heugens, P.P.M.A.R., 2013, 'Synthesizing and extending resource dependence theory: A meta-analysis', Journal of Management 39(6), 1666-1698. https://doi.org/10.1177/0149206312471391

Eminet, A. \& Guedri, Z., 2010, 'The role of nominating committees and director reputation in shaping the labour market for directors: An empirical assessment' Corporate Governance: An International Review 18(6), 557-574. https://doi. org/10.1111/j.1467-8683.2010.00814.x

Fracassi, C. \& Tate, G., 2012, 'External networking and internal firm governance', The Journal of Finance 67(1), 153-194. https://doi.org/10.1111/j.1540-6261.2011. 01706.x

Harjoto, M.A., Laksmana, I. \& Yang, Y.-W., 2018, 'Board diversity and corporate investment oversight', Journal of Business Research 90, 40-47. https://doi. org/10.1016/j.jbusres.2018.04.033

Hillman, A.T. \& Dalziel, T., 2003, 'Boards of directors and firm performance: Integrating agency and resource dependence perspectives', The Academy of Management Review 28(3), 383-396. https://doi.org/10.5465/amr.2003.10196729

Hom, C., Samson, D., Cregan, C. \& Cebon, P., 2021, 'Director independence: Going beyond misaligned incentives to resource dependence', Australian Journal of Management. https://doi.org/10.1177/03128962211009959

Institute of Directors in South Africa (IoDSA), 2009, King Report on corporate governance in South Africa, viewed 28 January 2020 , from https://cdn.ymaws. governance in South Africa, viewed 28 January 2020, from https://cdn.ymaws. 7F5A8B23FB3F/King_III_Code_for_Governance_Principles_.pdf.

Institute of Directors in South Africa (IoDSA), 2016, King Report on corporate governance in South Africa, viewed 28 January 2020, from https://www.saica. co.za/Technical/LegalandGovernance/King/tabid/2938/language/en-ZA/Default. co.za/Te
aspx.

International Corporate Governance Network (ICGN), 2018, Ensuring effective board succession planning, viewed 08 April 2020, from https://www.icgn.org/ensuringeffective-board-succession-planning.

Jensen, M.C. \& Meckling, W.H., 1976, 'Theory of the firm: Managerial behavior, agency costs and ownership structure', Journal of Financial Economics 3(4), 305360. https://doi.org/10.1016/0304-405X(76)90026-X

Johnson, S.G., Schnatterly, K. \& Hill, A.D., 2013, 'Board composition beyond independence: Social capital, human capital, and demographics', Journal of Management 39(1), 232-262. https://doi.org/10.1177/0149206312463938

Khanna, P., Jones, C.D. \& Boivie, S., 2014, 'Director human capital, information processing demands, and board effectiveness', Journal of Management 40(2), 557-585. https://doi.org/10.1177/0149206313515523

Kim, Y., Williams, R., Rothwell, W.J. \& Penaloza, P., 2014, 'A strategic model for technical talent management: A model based on a qualitative case study', Performance Improvement Quarterly 26(4), 93-121. https://doi.org/10.1002/piq.21159

Krause, R., Withers, M.C. \& Semadeni, M., 2017, 'Compromise on the board: Investigating the antecedents and consequences of lead independent director appointment', Academy of Management Journal 60(6), 2239-2265. https://doi. org/10.5465/amj.2015.0852 
Leblanc, R., 2020, The handbook of board governance: A comprehensive guide for public, private, and not-for-profit board members, 2 nd edn., Wiley, Hoboken, NJ.

Lenkov, P., 2020, 'Board director succession planning: Be purposeful and proactive', Forbes, viewed 09 June 2021, from https://www.forbes.com/sites/ patricialenkov/2020/05/26/board-director-succession-planning-be-purposefuland-proactive/?sh=ed834512eb60.

Livnat, J., Smith, G., Suslava, K. \& Tarlie, M., 2019, 'Do directors have a use-by date? Examining the impact of board tenure on firm performance', American Journal of Management 19(2), 97-125. https://doi.org/10.33423/ajm. v19i2.2073

Makarius, E.E. \& Srinivasan, M., 2017, 'Addressing skills mismatch: Utilizing talent supply chain management to enhance collaboration between companies and talent suppliers', Business Horizons 60(4), 495-505. https://doi.org/10.1016/j. talent suppliers', Busin
bushor.2017.03.007

Malan, D., 2017, What every leader needs to navigate the fourth industrial revolution viewed 08 June 2021, from https://www.weforum.org/agenda/2017/08/whatevery-leader-needs-to-navigate-the-fourth-industrial-revolution/

Mans-Kemp, N. \& Viviers, S., 2019, 'The role of nomination committees in diversifying boards in an emerging market context', Corporate Governance: The Internationa boards in an emerging market context', Corporate Governance: The International
Journal of Business in Society 19(4), 648-668. https://doi.org/10.1108/CG-07Journal of

Mans-Kemp, N., Viviers, S., Staal, B-M. \& Van Schalkwyk, J., 2018, 'Investigating director development in South Africa', Acta Commercii 18(1), a579. https://doi. org/10.4102/ac.v18i1.579

Minichilli, A., Nordqvist, M., Corbetta, G. \& Amore, D.M., 2014, 'CEO succession mechanisms, organizational context, and performance: A socio-emotional wealth perspective on family-controlled firms', Journal of Management Studies 51(7) perspective on family-controlled firms', Journal
1153-1179. https://doi.org/10.1111/joms.12095

Mulcahy, A., 2010, 'How I did it: Xerox's former CEO on why succession shouldn't be a horse race', Harvard Business Review 88(10), 47-52.

Nili, Y., 2020, 'The fallacy of director independence', Wisconsin Law Review 3, 491-514.

Ntim, C.G., 2015, 'Board diversity and organizational valuation: Unravelling the effects of ethnicity and gender', Journal of Management \& Governance 19, 167-195. https://doi.org/10.1007/s10997-013-9283-4

Odgers Berndtson, 2020, The Odgers Berndtson leadership confidence index, viewed 09 June 2021, from https://www3.odgersberndtson.com/LCI2020.

Pfeffer, J. \& Salancik, G.R., 1978, The external control of organizations: A resource dependence perspective, Harper \& Row, New York, NY.

PricewaterhouseCoopers (PwC), 2019, Workforce of the future, viewed 14 September 2020, from https://www.pwc.co.za/en/assets/pdf/workforce-forthe-future-2030.pdf

Schepker, D.J., Nyberg, A.J., Ulrich, M.D. \& Wright, P.W., 2018, 'Planning for future leadership: Procedural rationality, formalized succession processes, and CEO influence in CEO succession planning', Academy of Management Journal 61(2), 523-552. https://doi.org/10.5465/amj.2016.0071

Scrope, K., Braithwaite, M. \& Potter, S., 2020, 'Companies face a crisis of confidence in their business leaders', in Odgers Berndtson, viewed 31 March 2020, from https:// www.odgersberndtson.com/en-sg/insights/companies-face-a-crisis-of confidence-in-their-business-leaders.
Seekings, J., 2008, 'The continuing salience of race: Discrimination and diversity in South Africa', Journal of Contemporary African Studies 26(1), 1-25. https://doi. org/10.1080/02589000701782612

Shaw, J.D., Park, T.Y. \& Kim, E., 2013, 'A resource-based perspective on human capital losses, HRM investments, and organizational performance', Strategic Management Journal 34(5), 572-589. https://doi.org/10.1002/smj.2025

Shen, W. \& Cho, T.S., 2005, 'Exploring involuntary executive turnover through a managerial discretion framework', Academy of Management Review 30(1) 169-175. https://doi.org/10.5465/amr.2005.18378881

Spencer Stuart, 2018, The road to strategic board succession, viewed 09 June 2021, from https://www.spencerstuart.com/research-and-insight/the-road-to-strategic-boardsuccession.

Stephan, A., Kamen, M. \& Bannister, C., 2017, 'Tech fluency: A foundation of future careers', Deloitte Review 21, 80-93.

Sun, X.S. \& Bhuiyan, M.B.U., 2020, 'Board tenure: A review', The Journal of Corporate Accounting \& Finance 31(4), 178-196. https://doi.org/10.1002/jcaf.22464

Tao, R. \& Zhao, H., 2019, “"Passing the baton": The effects of CEO succession planning on firm performance and volatility', Corporate Governance: An International Review 27(1), 61-78. https://doi.org/10.1111/corg.12251

Valentine, E. \& Stewart, G., 2013, 'The emerging role of the board of directors in enterprise business technology governance', International Journal of Disclosure and Governance 10, 346-362. https://doi.org/10.1057/jdg.2013.11

Van den Berghe, L.A.A. \& Baelden, T., 2005, 'The complex relation between director independence and board effectiveness', Corporate Governance: The Internationa Journal of Business in Society 5(5), 58-83. https://doi.org/10.1108/1472070 0510630068

Vasileiou, K., Barnett, J., Thorpe, S. \& Young, T., 2018, 'Characterising and justifying sample size sufficiency in interview-based studies: Systematic analysis of qualitative health research over a 15-year period', BMC Medical Research Methodology 18, 148. https://doi.org/10.1186/s12874-018-0594-7

Viviers, S., Mans-Kemp, N. \& Fawcett, R., 2017, 'Mechanisms to promote board gender diversity in South Africa', Acta Commercii 17(1), a489. https://doi org/10.4102/ac.v17i1.489

Volonté, C. \& Gantenbein, P., 2016, 'Directors' human capital, firm strategy, and firm performance', Journal of Management \& Governance 20, 115-145. https://doi. org/10.1007/s10997-014-9304-y

Wallace, M. \& Webber, L., 2017, The disaster recovery handbook: A step-by-step plan to ensure business continuity and protect vital operations, facilities, and assets, 3 rd edn., Amacom, New York, NY.

Wang, C.Y.-P., Jaw, B.-S. \& Tsai, C.H.-C., 2012, 'Building dynamic strategic capabilities: A human capital perspective', The International Journal of Human Resource Management 23(6), 1129-1157. https://doi.org/10.1080/09585192.2011.561234

Whysall, Z., Owtram, M. \& Brittain, S., 2019, 'The new talent management challenges of Industry 4.0', Journal of Management Development 38(2), 118-129. https:// doi.org/10.1108/JMD-06-2018-0181

Zhang, Y. \& Rajagopalan, N., 2006, 'Grooming for the top post and ending the CEO succession crisis', Organisational Dynamics 35(1), 96-105. https://doi. org/10.1016/j.orgdyn.2005.12.007

Zhang, Y. \& Rajagopalan, N., 2010, 'CEO succession planning: Finally at the center stage of the boardroom', Business Horizons 53(5), 455-462. https://doi org/10.1016/j.bushor.2010.05.003 